
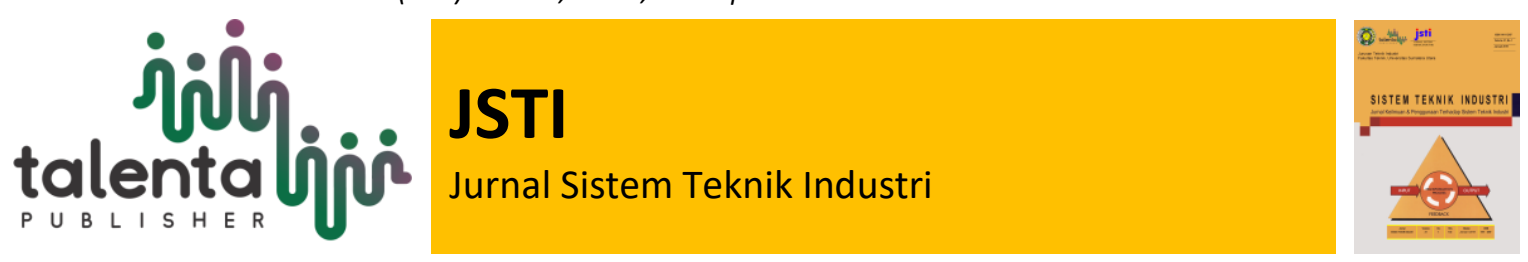

\title{
Performansi Pipa Bersirip Alat Penukar Kalor Udara- Tanah Menggunakan Siklus Terbuka
}

\section{Terang UHSG Manik, Tulus Burhanuddin Sitorus ${ }^{2}$, Mangontang Situmorang ${ }^{3}$}

1,2,3 Departemen Teknik Mesin, Fakultas Teknik, Universitas Sumatera Utara, Medan, Indonesia ${ }^{2}$ PUI Energi Berkelanjutan dan Biomaterial

\begin{abstract}
In heat exchanger analysis using the Earth Air Heat Exchanger method, the overall heat transfer coefficient is known. This tool uses tubes in its design. The weakness of tube and plate type heat exchangers is the relatively low heat transfer coefficient, which can only reach a maximum of $60 \%$. Therefore, a method to improve the heat transfer efficiency is using a fin. The purpose of this study is to calculate and compare the effectiveness $(\varepsilon)$ value of experimental and theoretical of the Earth Air Heat Exchanger, as well as to find out the value of the coefficient of performance. The result showed that the average COP value of the experimental result is 0.63 at a speed of $1 \mathrm{~m} / \mathrm{s}, 0.54$ at the speed of $2 \mathrm{~m} / \mathrm{s}$, and 0.75 at the speed of $3 \mathrm{~m} / \mathrm{s}$, while theoretically is 0,73 at $1 \mathrm{~m} / \mathrm{s}, 0.57$ at $2 \mathrm{~m} / \mathrm{s}$, and 0.80 at $3 \mathrm{~m} / \mathrm{s}$. For the value of the average effectiveness of the experimental results obtained 0.85 at the speed of $1 \mathrm{~m} / \mathrm{s}, 0.93$ at the speed of $2 \mathrm{~m} / \mathrm{s}$, and 0.89 at the speed of $3 \mathrm{~m} / \mathrm{s}$, while the theoretical result is 0.995 at the speed of $1 \mathrm{~m} / \mathrm{s}, 0.997$ at $2 \mathrm{~m} / \mathrm{s}$, and 0.998 at $3 \mathrm{~m} / \mathrm{s}$.
\end{abstract}

Keyword: Earth Air Heat Exchanger, Coefficient of Performance, Overall Heat Transfer Coefficient

\begin{abstract}
Abstrak. Pendinginan ruangan mempergunakan metode sistem transfer kalor pada lapisan tanah atau Earth Air Heat Exchanger (EAHE). Dalam analisis perangkat pengubah panas, dikenal koefisien transfer kalor keseluruhan (Overall Heat Transfer Coefficient). Heat exchanger tipe ini menggunakan tube pada desainnya. Kekurangan dari heat exchanger bertipe tubular dan plat adalah koefisien transfer kalor yang relatif rendah, hanya dapat mencapai maksimal 60\%. Sehingga salah satu metode untuk menningkatkan efisiensi transfer kalor adalah dengan cara memperluas permukaan dengan mempergunakan sirip. Tujuan penelitian ini adalah untuk menghitung dan membandingkan nilai efektivitas $(\varepsilon)$ dari alat penukar kalor udara tanah hasil eksperimen dan teoritis, dan juga mengetahui nilai Coeficient of Performance secara teoritis dan eksperimen. Hasil yang didapatkan yaitu nilai COP rata-rata resultan percobaan merupakan 0,63 dalam kelajuan $1 \mathrm{~m} / \mathrm{s}$, 0,54 dalam kelajuan $2 \mathrm{~m} / \mathrm{s}$, dan 0,75 dalam kelajuan $3 \mathrm{~m} / \mathrm{s}$, sedangkan secara teoritis didapatkan 0,73 dalam kelajuan $1 \mathrm{~m} / \mathrm{s}, 0,57$ dalam kelajuan $2 \mathrm{~m} / \mathrm{s}, 0,80$ dalam kelajuan $3 \mathrm{~m} / \mathrm{s}$. Pada nilai tingkat keefektifan rata-rata dari resultan percobaan diperoleh 0,85 dalam kelajuan $1 \mathrm{~m} / \mathrm{s}$, 0,93 dalam kelajuan $2 \mathrm{~m} / \mathrm{s}$ dan 0,89 dalam kelajuan $3 \mathrm{~m} / \mathrm{s}$, sedangkan resultan secara

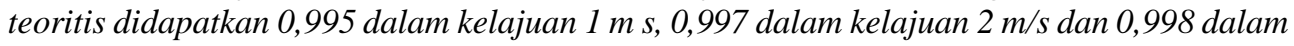
kelajuan $3 \mathrm{~m} s$
\end{abstract}

Kata Kunci: Earth Air Heat Exchanger, Coefficient of Performance, Overall Heat Transfer Coefficient

Received 10 January 2021 | Revised 18 January 2021 | Accepted 25 January 2021

*Corresponding author at: Jln. Almameter Kampus USU, Medan, 20155, Indonesia

E-mail address: terang1@usu.ac.id 


\section{Pendahuluan}

Saat ini dalam hal pemanfaatan energi, setiap orang berlomba-lomba mencari sumber energi alternatif. Indonesia adalah negara tropik yang hanya memiliki dua musim, yaitu musim kemarau dan musim hujan [1]. Pada musim kemarau terjadi peningkatan temperatur, Dengan adanya pemanasan global mengakibatkan peningkatan temperatur di daerah tropis meningkat pesat [2]. Untuk mengatasi kenaikan suhu ini, masyarakat biasanya menggunakan AC (AC) dan kipas angin untuk mendinginkan ruangan, karena $\mathrm{AC}$ dan kipas angin memerlukan energi yang lebih banyak, sehingga hanya energi sekitar yang digunakan saat mendinginkan ruangan, misalnya menggunakan metode heat transfer system. Lapisan tanah atau penukar panas udara bumi (EAHE) [3].

Sistem transfer kalor pada lapisan tanah merupakan proses mendinginkan udara yang mempergunakan tanah selaku adsorben panas. Udara disalurkan melalui pipa yang ditanam dalam tanah berubah menjadi dingin karena panas dalam udara akan diabsorbsi oleh tanah, hal ini terjadi karena perbedaan temperatur antara tanah dan udara yang mengalir dalam pipa [4]. Pemanfaatan metode system perpindahan panas pada lapisan tanah ini, mengurangi penggunaan energi yang mana energi yang kita pergunakan dalam keseharian berasal dari bahan bakar fosil yang jumlahnya makin hari semakin berkurang.

Studi ini dilakukan bertujuan untuk mengetahui temperature dan pengaruh kecepatan fluida terhadap penurunan pada suhu keluar $\left(\mathrm{T}_{\text {out }}\right.$ ) pipa tanam yakni, yang terjadi secara eksperimen dan teoritis. Kemudian, dilakukan penghitungan dan pembandingan nilai efektivitas $(\varepsilon)$ dari alat penukar kalor udara tanah hasil eksperimen dan teoritis, termasuk untuk memahami nilai Coeficient of Performance pada pipa tanam bawah tanah [5].

Riset ini difokuskan kepada beberapa hal agar hasil yang dicapai sesuai dengan maksud dan tujuan penelitian. Pertama, sistem perpindahan panas pada lapisan tanah menggunakan siklus terbuka. Kedua, aliran fluida diasumsikan turbulen. Ketiga, temperatur dalam pipa dianggap seragam dalam sumbu aksial, dan Keempat, fluida penghantar panas yang digunakan adalah udara.

Jika dimensi dari sebuah sistem EAHE diketahui, perhitungan laju perpindahan panas dapat dihitung menggunakan metode log mean temperature difference (LMTD) atau menggunakan metode bilangan NTU [6]. Dalam penelitian ini menggunakan metode e-NTU. Temperatur udara keluar ditentukan menggunakan rumus keefektivitasan dari EAHE yang merupakan fungsi unit bilangan transfer (NTU). Nilai NTU terdiri dari tiga parameter,yaitu : koefisien perpindahan panas konveksi (h), luas penampang dalam pipa (A), laju aliran massa (m) yang nilainya bervariasi [7]. Luas penampang bagian dalam pipa adalah fungsi dari diameter, D, dan panjang pipa dari alat penukar kalor udara-tanah, rumusnya adalah sebagai berikut:

$$
\mathrm{A}=\pi \mathrm{DL}
$$

Koefisien perpindahan panas konveksi didalam pipa ditentukan dengan rumus: 


$$
h=\frac{N u K}{D}
$$

Sebuah sistem EAHE dapat diasumsikan bahwa permukaan dalam pipa yang digunakan dalam EAHE adalah halus, hubungan bilangan $\mathrm{Nu}$ diberikan oleh [8] dapat digunakan untuk mensimulasikan performansi dari system, dengan menggunakan rumus:

$$
N u=\frac{f / 8(\operatorname{Re}-1000) \operatorname{Pr}}{1+12.7 \sqrt{(f / 8)}\left(\operatorname{Pr}^{2} / 3-1\right)}
$$

Untuk aliran turbulen dengan bilangan Reynold $2300<\operatorname{Re}<5$ x 10-6 dan permukaan halus maka digunakan persamaan berikut untuk menghitung koefisien gesek [9]:

$$
f=(1.82 \log \mathrm{Re}-1.64)^{-2}
$$

Sementara itu, bilangan Reynold berhubungan dengan rata-rata kecepatan udara dan diameter menggunakan persamaan [10]:

$$
R e=\frac{\rho v_{a} D}{\mu}
$$

Total perpindahan panas dari udara ketika mengalir didalam pipa ditentukan melalui:

$$
Q_{h}=\dot{\mathrm{m}} C_{p}\left(T_{\text {out }}-T_{\text {in }}\right)
$$

Apabila disebabkan oleh konveksi antara aliran udara dengan dinding pipa, maka perpindahan panas dapat ditentukan :

$$
Q_{h}=h A \Delta T_{l m}
$$

dimana $\Delta T_{l m}$ adalah logaritma dari perbedaan temperatur rata-rata, didapat melalui $\left(T_{\text {soil }}=\right.$ $\left.T_{\text {wall }}\right)[11]$ :

$$
\Delta T_{l m}=\frac{T_{\text {in }}-T_{\text {out }}}{\ln \left\lceil\frac{T_{\text {in }}-T_{\text {wall }}}{T_{\text {out }}-T_{\text {wall }}}\right\rceil}
$$

Temperatur udara pada sisi keluar pipa sistem penukar kalor tanah-udara $\left(T_{\text {out }}\right)$ dapat ditentukan dalam bentuk fungsi eksponensial [12] dari temperatur dinding pipa $\left(T_{\text {wall }}\right)$ dan temperatur pada sisi masuk $\left(T_{\text {in }}\right)$ dengan mengeliminasi $Q_{h}$ dari persamaan (4) dan (5).

$$
T_{\text {out }}=T_{\text {wall }}+\left(T_{\text {in }}-T_{\text {wall }}\right) e^{-\left(\frac{h A}{\dot{m} C p}\right)}
$$

Jika dimisalkan pipa dengan panjang yang tak terhingga $(\mathrm{A}=\infty)$, maka udara akan didinginkan setingkat dengan suhu dinding dalam pipa. Sehingga rumus keefektivitasan dari perangkat pengubah panas udara-tanah adalah:

$$
\varepsilon=\frac{\text { Tin-Tout }}{\text { Tin-Twall }}=1-e^{-(h A / \dot{m} C p)}
$$


Sementara itu, untuk nilai bilangan NTU:

$$
N T U=\frac{h A}{\dot{\mathrm{m} C p}} \varepsilon=\frac{\text { Tin-Tout }}{\text { Tin-Twall }}=1-e^{-(h A / \dot{\mathrm{m} C p})}
$$

sehingga diperoleh persamaan [13]:

$$
\varepsilon=1-e^{-N T U}
$$

Keefektivitasan dari sebuah alat penukar kalor udara tanah ditentukan dengan bilangan NTU. Dengan meningkatnya nilai NTU, maka nilai keefektivitasan akan semakin meningkat namun kurvanya akan semakin rata. Pertambahan nilai keefektivitasan akan semakin kecil apabila nilai NTU lebih besar dari 3 .

Koefisien performansi atau sering disingkat COP adalah rasio antara kapasitas pendinginan dari alat penukar kalor udara-tanah $Q_{c}$ dengan konsumsi daya listrik pada peralatan mekanis seperti blower, menggunakan persamaan [14]:

$$
C O P=\frac{Q_{c}}{P_{f}}
$$

dimana $P_{f}$ adalah daya yang dibutuhkan oleh blower (Watt), $Q_{c}$ adalah kapasitas pendinginan (Watt),

$$
Q_{c}=\dot{\mathrm{m}} . C_{p}\left(T_{\text {in }}-T_{\text {out }}\right)
$$

dimana ṁ merupakan laju aliran massa $(\mathrm{kg} / \mathrm{s})$, adalah kapasitas kalor spesifik udara $(\mathrm{J} / \mathrm{kgK})$, adalah temperatur pada sisi masuk (K), dan $T_{\text {out }}$ adalah temperatur pada sisi keluar (K).

\section{Metodologi Penelitian}

\subsection{Material}

Untuk mendukung hasil penelitian yang maksimal sesuai denga tujuan yang ingin dicapai, maka didalam melakukan eksperimen, peneliti menggunakan beberapa alat dan bahan, yaitu blower, inverter, pipa dan sambungan pipa, instrumen pengukuran, Cole Palmer 18200-40, termokopel, dan anemometer.

\subsection{Pengambilan Data}

Gambar 1 menampilkan dimensi dari perangkat pengubah panas udara-tanah secara skematik. 


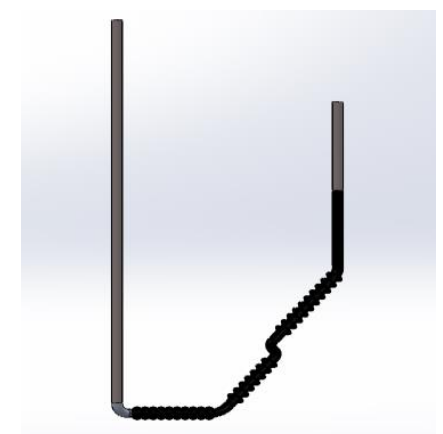

\section{Gambar 1 Desain Perangkat Pengubah Panas Udara-Tanah}

Pipa yang dipergunakan adalah pipa dengan bahan mildstell seperti tampak pada gambar 3. Pipa memiliki diameter dalam $\left(D_{i}\right)$ sebesar $0,0625 \mathrm{~m}$. Panjang total keseluruhan pipa sebesar 5,92 m dan panjang pipa yang ditanam horisontal pada kedalaman $2 \mathrm{~m}$ adalah $0,66 \mathrm{~m}$.

Pipa kemudian akan ditanam pada kedalaman 2 m seperti tampak pada gambar 4. Ukuran lubang disiapkan 2 x $1 \mathrm{~m}$ dengan kedalaman $2 \mathrm{~m}$. Tanah pada kedalaman $2 \mathrm{~m}$ berjenis tanah lempung yang padat dan keras.

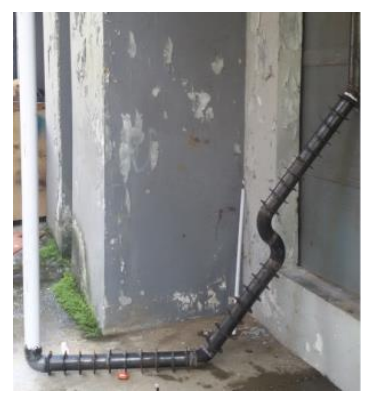

Gambar 2 Rangkaian Pipa

Pipa dirangkai dan disambung terlebih dahulu diatas permukaan tanah. Hal ini bertujuan untuk memberikan waktu agar lem pada tiap sambungan pipa dapat mengering dengan sempurna.

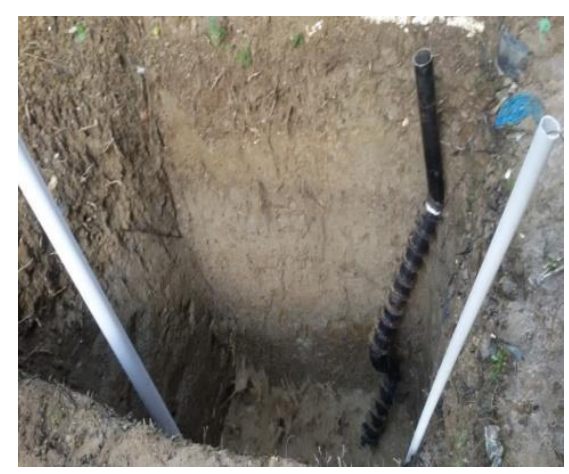

Gambar 3 Penimbunan Pipa 


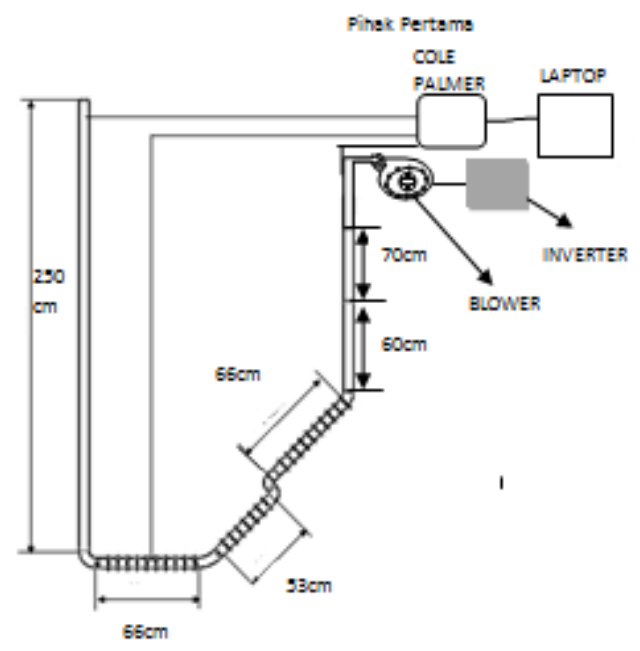

Gambar 4 Skema Eksperimen

Gambar 4 menampilkan skema eksperimental penelitian. Termokopel yang diletakkan pada titik pengukuran temperatur sepanjang pipa dan dihubungkan dengan komputer menggunakan data akuisisi Cole-Palmer 18200-40 8 chanel. Zona diletakkan sepanjang pipa horizontal. Dan satu titik termokopel diletakkan pada kedalaman tanah $2 \mathrm{~m}$ serta pada titik $0,5 \mathrm{~m}$ diatas permukaan tanah untuk mengukur temperatur lingkungan. Hasil akuisisi ditampilkan dalam bentuk data dan grafik menggunakan software Tracer-Daq. Data yang diperoleh kemudian disimpan dalam bentuk file .txt.

\section{Hasil dan Pembahasan}

Pada studi ini, analisa perpindahan panas alat penukar kalor udara tanah ini diasumsikan temperatur dinding pipa dalam sumbu-x seragam, dan perpindahan panas dianalisa pada pipa yang ditanam. Pipa yang digunakan berjenis MIDL STEEL dengan diameter 3 inchi atau 0,0742 $\mathrm{m}$ dan dengan panjang 26,5 m. Maka, didalam eksperimen, peneliti menggunakan beberapa alat dan bahan, yaitu blower, inverter, pipa dan sambungan pipa, instrument pengukuran, Cole Palmer 18200-40, termokopel dan nanometer.

\subsection{Temperatur Keluaran}

Gambar 5 menunjukkan suhu input rata-rata diperoleh sebesar $30,64^{\circ} \mathrm{C}$ dan Suhu output rata-rata adalah sebesar $25,24^{\circ} \mathrm{C}$.

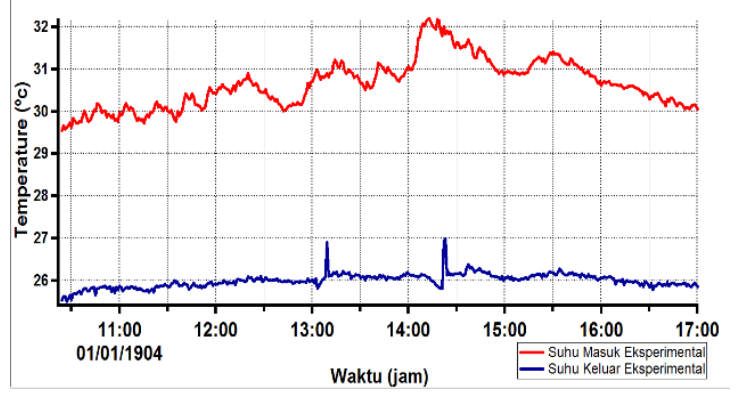

Gambar 5 suhu Keluaran Teoritis untuk $V_{\text {udara }}=1 \mathrm{~m} / \mathrm{s}$ 
Gambar 5 menunjukkan bahwa penukar panas udara-tanah dapat menurunkan suhu rata-rata sebesar $5,4^{\circ} \mathrm{C}$. Sementara itu, Gambar 6 menunjukkan temperatur input rata-rata $30,23^{\circ} \mathrm{C}$ dan temperatur output rata-rata $26,06^{\circ} \mathrm{C}$..

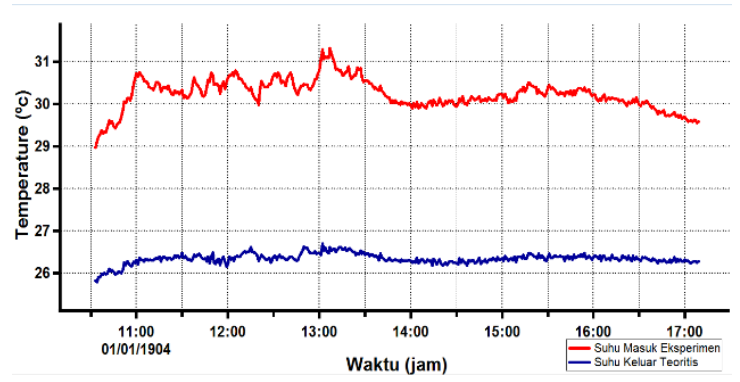

Gambar 6 Suhu Keluaran Teoritis untuk $V_{\text {udara }}=2 \mathrm{~m} / \mathrm{s}$

Gambar 6 diatas menunjukkan bahwa alat Earth Air Heat Exchanger (EAHE) dianggap mampu menurunkan suhu rata-rata sebesar $4,17^{\circ} \mathrm{C}$. Pada Gambar 9, menunjukkan Suhu input rata-rata diperoleh sebesar $31,38^{\circ} \mathrm{C}$ dan suhu output rata-rata adalah sebesar $25,65^{\circ} \mathrm{C}$.

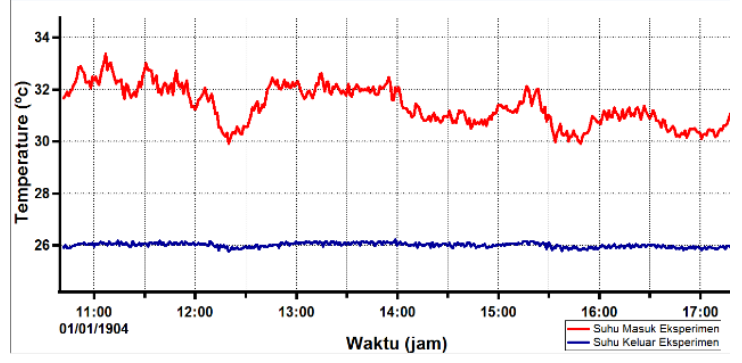

Gambar 7 Suhu Keluaran Teoritis untuk $V_{\text {udara }}=3 \mathrm{~m} / \mathrm{s}$

Gambar 7 diatas menunjukkan bahwa alat Earth Air Heat Exchanger (EAHE) dianggap mampu menurunkan suhu rata-rata sebesar $4,73^{\circ} \mathrm{C}$.

Dari ketiga grafik diatas didapat nilai $T_{\text {out }}$ rata-rata sebagai berikut:

Tabel 1 Temperatur Keluaran $\left(T_{\text {out }}\right)$ Teoritis

\begin{tabular}{cccc}
\hline Tanggal & $V_{\text {udara }}(\mathrm{m} / \mathrm{s})$ & Statistik & $T_{\text {out }}\left({ }^{\circ} \mathrm{C}\right)$ \\
\hline $20 / 04 / 18$ & 1 & Rata-rata & 27.2453 \\
$24 / 04 / 18$ & 2 & Rata-rata & 26.0647 \\
$27 / 04 / 18$ & 3 & Rata-rata & 25,8690 \\
\hline
\end{tabular}

Secara teoritis dapat diliha8 dari tabel 1 bahwa dengan meningkatnya kecepatan udara masuk $\left(V_{\text {udara }}\right)$ maka temperatur keluaran $\left(T_{\text {out }}\right)$ akan semakin menurun. Pada kecepatan $1 \mathrm{~m} / \mathrm{s}$ temperatur keluaran rata-rata sebesar $27,24^{\circ} \mathrm{C}$ dan menurun sampai $25,86^{\circ} \mathrm{C}$ untuk kecepatan udara $3 \mathrm{~m} / \mathrm{s}$.

\subsection{Perbandingan Temperatur Keluaran Eskperimental vs Teori}

Gambar 8 dibawah ini menampilkan grafik perbandingan $T_{\text {out }}$ teoritis dan eksperimental. 


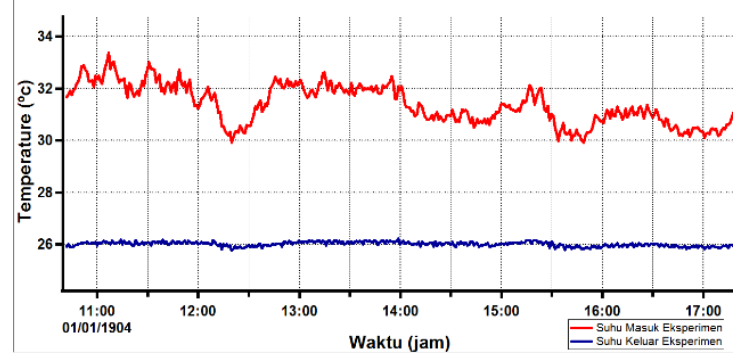

Gambar 8 Perbandingan $T_{\text {out }}$ Eksperimental dan Teoritis $\left(V_{\text {udara }}=1 \mathrm{~m} / \mathrm{s}\right)$

Sementara itu, Gambar 9, menampilkan perbandingan $T_{\text {out }}$ teoritis dan eksperimental untuk $V_{\text {udara }}$ $=2 \mathrm{~m} / \mathrm{s}$.

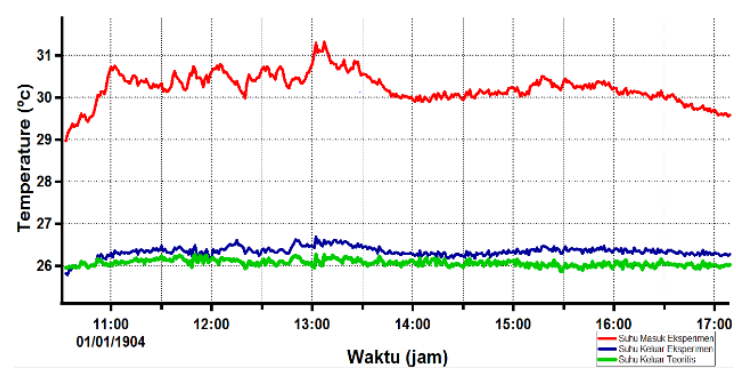

Gambar 9 Perbandingan $T_{\text {out }}$ Eksperimental dan Teoritis $\left(V_{\text {udara }}=2 \mathrm{~m} / \mathrm{s}\right)$

Gambar 10 dibawah menunjukkan grafik perbandingan $T_{\text {out }}$ teoritis dan eksperimental untuk $V_{\text {udara }}=3 \mathrm{~m} / \mathrm{s}$.

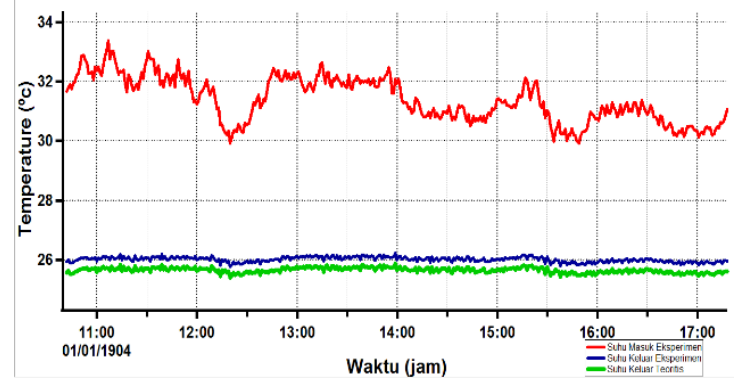

Gambar 10 Perbandingan $T_{\text {out }}$ Eksperimental dan Teoritis $\left(V_{\text {udara }}=3 \mathrm{~m} / \mathrm{s}\right)$

Dari ketiga grafik, dapat kita ambil nilai rata-rata suhu output baik untuk hasil teoritis begitupun eksperimental seperti ditunjukkan dalam Tabel 2, sebagai berikut.

Tabel 2 Perbandingan Suhu Output Percobaan dan Teoritis

\begin{tabular}{cccccc}
\hline \multirow{2}{*}{$\mathrm{V}_{\text {udara }}$} & \multirow{2}{*}{ Statistik } & \multirow{2}{*}{$\mathrm{T}_{\text {in }}\left({ }^{\circ} \mathrm{C}\right)$} & \multicolumn{2}{c}{$\mathrm{T}_{\text {out }}\left({ }^{\circ} \mathrm{C}\right)$} & \multirow{2}{*}{ Galat } \\
\cline { 4 - 5 } & & Eksperimental & Teoritis & \\
2 & $\max$ & 32,19 & 26,99 & 26,06 & $0,67 \%$ \\
3 & $\max$ & 31,32 & 26,69 & 25,01 & $1,02 \%$ \\
\hline
\end{tabular}


Tabel 2 di atas menampilkan bahwa kesalahan suhu keluaran rata-rata $\left(\mathrm{T}_{\text {out }}\right)$ yang diberikan oleh model eksperimental dan model teoritis bervariasi antara $0,67 \%$ dan $1,44 \%$. Suhu udara keluaran rata-rata dari pengubah panas menurun bersamaan dengan meningkatnya kecepatan udara yang memasuki pengubah panas udara-tanah. Suhu keluaran rata-rata eksperimental lebih tinggi dari suhu keluaran teoritis rata-rata.

\subsection{Performansi Termal Alat Penukar Kalor Udara-Tanah}

\section{A. Performansi secara Teoritis}

Dengan menggunakan persamaan (14), maka didapat nilai efektivitas alat penukar kalor secara teoritis sebagaimana ditunjukkan pada Tabel 3sebagai berikut:

Tabel 3 Nilai NTU

\begin{tabular}{ccc}
\hline$V_{\text {udara }}(\mathrm{m} / \mathrm{s})$ & Statistik & NTU \\
\hline 1 & Maksimum & 1,5147 \\
& Rata-rata & 1,5144 \\
2 & Maksimum & 1,2185 \\
& Rata-rata & 1,2130 \\
3 & Maksimum & 1,2683 \\
& Rata-rata & 1,2656 \\
\hline
\end{tabular}

B. Performansi secara Eksperimental

Untuk mendeterminasikan keefektivitasan perangkat pengubah panas (e) untuk data hasil percobaan didapat dari persamaan (13), sebagaimana ditunjukkan melalui Tabel 4 berikut:

Tabel 4 Efektivitas Eksperimental dari Alat Penukar Kalor Udara-Tanah

\begin{tabular}{ccc}
\hline$V_{\text {udara }}(\mathrm{m} / \mathrm{s})$ & Statistik & Efektivitas $(\varepsilon)$ Eksperimental \\
\hline \multirow{2}{*}{1} & Maksimum & 0,954 \\
2 & Rata-rata & 0,859 \\
& Maksimum & 0,883 \\
3 & Rata-rata & 0,816 \\
& Maksimum & 0,923 \\
& Rata-rata & 0,897 \\
\hline
\end{tabular}

Dari Tabel 4 diatas, dapat dicermati bahwasanya efektivitas rata-rata alat Earth Air Heat Exchanger (EAHE) pada kecepatan udara masuk 3m/s lebih tinggi dibandingkan dengan kecepatan udara masuk $1 \mathrm{~m} / \mathrm{s}$ maupun pada kecepatan $2 \mathrm{~m} / \mathrm{s}$. Sementara itu, nilai tertinggi dari efektivitas alat Earth Air Heat Exchanger (EAHE) dicapai pada kelajuan udara masuk $1 \mathrm{~m} / \mathrm{s}$ sebesar 0,954. Berdasarkan perhitungan pada tabel 2 dan 3, maka dapat diketahui perbandigan efektivitas eksperimental dengan efektivitas teoritis sebagaimana ditunjukkan pada Tabel 5.

Nilai efektivitas alat Earth Air Heat Exchanger (EAHE) secara teoritis didapat dari fungsi hubungan antara NTU dan e, dengan menggunakan persamaan (12). 
Tabel 5 Perbandingan Efektivitas Eksperimental dengan Efektivitas Teoritis

\begin{tabular}{ccccc}
\hline $\begin{array}{c}V_{\text {udara }} \\
(\mathrm{m} / \mathrm{s})\end{array}$ & Statistik & $\begin{array}{c}\text { Efektivitas }(\varepsilon) \\
\text { Teoritis }\end{array}$ & $\begin{array}{c}\text { Efektivitas }(\varepsilon) \\
\text { Eksperimental }\end{array}$ & Perbedaan (\%) \\
\hline \multirow{2}{*}{1} & Maksimum & 0,995 & 0,954 & 4,08 \\
& Rata-rata & 0,995 & 0,859 & 13,70 \\
2 & Maksimum & 0,997 & 0,883 & 11,44 \\
& Rata-rata & 0,997 & 0,816 & 18,17 \\
3 & Maksimum & 0,998 & 0,923 & 7,55 \\
& Rata-rata & 0,998 & 0,897 & 10,15 \\
\hline
\end{tabular}

Tabel 5 diatas menunjukkan bahwa keefektivitasan alat Earth Air Heat Exchanger (EAHE) dipengaruhi kecepatan udara masuk. Hal ini dibuktikan berdasarkan eksperimen rata-rata bahwa pada saat alat penukar kalor diberi kecepatan udara masuk $\left(V_{\text {udara }}\right)$ sebesar $1 \mathrm{~m} / \mathrm{s}$, keefektivitasan alat penukar kalor ini sebesar 0,859 . Seiring dengan peningkatan kecepatan udara masuk menjadi $2 \mathrm{~m} / \mathrm{s}$, keefektivitasan rata-rata sebesar 0,816, Namun pada kelajuan udara masuk $3 \mathrm{~m} / \mathrm{s}$ keefektifitasan rata-rata adalah 0,897 .

\subsection{Nilai Koefisien Performansi (Coefficient of Performance)}

Dengan mengunakan persamaan (13) dan (14), maka diperoleh nilai kapasitas pendinginan (cooling capacity) secara eksperimental, sebagai berikut.

Tabel 6 Kapasitas Pendinginan secara Eksperimental

\begin{tabular}{ccc}
\hline$V_{\text {udara }}(\mathrm{m} / \mathrm{s})$ & Statistik & NTU \\
\hline \multirow{2}{*}{1} & Maksimum & 31,47 \\
& Rata-rata & 23,27 \\
2 & Maksimum & 47,03 \\
& Rata-rata & 39,05 \\
\multirow{2}{*}{3} & Maksimum & 108,55 \\
& Rata-rata & 80,43 \\
\hline
\end{tabular}

Dari Tabel 6 diatas, diketahui bahwa kapasitas pendingin dengan kelajuan udara masuk $\left(V_{\text {udara }}\right)$ sebesar $1 \mathrm{~m} / \mathrm{s}$ adalah 31,47 W, nilai kapasitas pendingin meningkat menjadi 108,55 W seiring dengan meningkatnya kelajuan udara masuk $\left(V_{\text {udara }}\right)$ menjadi $3 \mathrm{~m} / \mathrm{s}$. Sementara itu, Tabel 7 menunjukkan nilai kapasitas pendinginan secara teoritis.

Tabel 7 Kapasitas Pendinginan secara Teoritis

\begin{tabular}{ccccc}
\hline $\begin{array}{c}V_{\text {udara }} \\
(\mathrm{m} / \mathrm{s})\end{array}$ & Statistik & $\begin{array}{c}\text { Efektivitas }(\varepsilon) \\
\text { Teoritis }\end{array}$ & $\begin{array}{c}\text { Efektivitas }(\varepsilon) \\
\text { Eksperimental }\end{array}$ & Perbedaan $(\%)$ \\
\hline \multirow{2}{*}{1} & Maksimum & 34,50 & 31,47 & $8,786 \%$ \\
& Rata-rata & 27,00 & 23,27 & $13,81 \%$ \\
2 & Maksimum & 57,03 & 47,03 & $17,53 \%$ \\
& Rata-rata & 47,73 & 39,05 & $18,18 \%$ \\
3 & Maksimum & 114,80 & 108,55 & $4,778 \%$ \\
& Rata-rata & 85,80 & 80,43 & $6,262 \%$ \\
\hline
\end{tabular}


Daya yang dipergunakan bertambah bersamaan dengan penambahan load pada alat penghembus untuk menciptakan kecepatan udara. Harus diketahui bahwa nilai penggunaan daya yang dipergunakan harus paling tidak kurang dari kapasitas pendinginan penukar panas udara-tanah.

Dari Tabel 8, dapat dilihat bahwa dengan peningkatan kelajuan udara masuk ( $\left.V_{\text {udara }}\right)$ melalui 1 m/s ke 2, dan 3 m / s, maka nilai COP perangkat Earth Air Heat Exchanger (EAHE) meningkat sebesar 1,01 dari 0,85. Maximum COP value diperoleh dengan kelajuan udara masuk $3 \mathrm{~m} / \mathrm{s}$ sebesar 1,01. Maka nilai COP alat penukar kalor udara-tanah dari hasil eksperimental dapat diketahui sebagaimana ditunjukkan pada Tabel 8 sebagai berikut.

Tabel 8 Nilai COP Hasil Eksperimen

\begin{tabular}{ccc}
\hline $\begin{array}{c}V_{\text {udara }} \\
(\mathrm{m} / \mathrm{s})\end{array}$ & Statistik & COP \\
\hline \multirow{2}{*}{1} & Maksimum & 0,85 \\
& Rata-rata & 0,63 \\
2 & Maksimum & 0,65 \\
& Rata-rata & 0,54 \\
3 & Maksimum & 1,01 \\
& Rata-rata & 0,75 \\
\hline
\end{tabular}

Sementara itu, Tabel 9 menunjukkan hasil COP alat penukar kalor udara-tanah berdasarkan hasil perhitungan teoritis.

Tabel 9 Perbandingan Coefficient of Performance Teoritis dengan Eksperimental

\begin{tabular}{ccccc}
\hline $\begin{array}{c}V_{\text {udara }} \\
(\mathrm{m} / \mathrm{s})\end{array}$ & Statistik & COP Teoritis & $\begin{array}{c}\text { COP } \\
\text { Eksperimental }\end{array}$ & Perbedaan $(\%)$ \\
\hline \multirow{2}{*}{1} & Maksimum & 0,93 & 0,85 & $8,786 \%$ \\
& Rata-rata & 0,73 & 0,63 & $13,81 \%$ \\
2 & Maksimum & 0,79 & 0,65 & $17,53 \%$ \\
& Rata-rata & 0,66 & 0,54 & $18,18 \%$ \\
3 & Maksimum & 1,06 & 1,01 & $4,77 \%$ \\
& Rata-rata & 0,80 & 0,75 & $6,262 \%$ \\
\hline
\end{tabular}

Nilai COP yang diberikan dari hasil teori juga menunjukkan gejala yang sama dengan hasil eksperimental. Dimana COP meningkat dengan bertambahnya kelajuan aliran udara masuk melalui $1 \mathrm{~m} / \mathrm{s}$ ke $3 \mathrm{~m} / \mathrm{s}$. Dari data Tabel 9 diatas, diketahui bahwa kecepatan udara masuk $3 \mathrm{~m} / \mathrm{s}$ menghasilkan nilai COP rata-rata yang paling tinggi. Hal ini disebabkan karena konsumsi daya blower tinggi tidak disertai dengan Cooling Capacity yang tinggi.

Grafik pada Gambar 11 berikut ini menampilkan hubungan antara bilangan NTU dengan COP untuk tiap kecepatan udara masuk. Grafik hubungan NTU dengan COP pada kecepatan udara masuk 2 m/s ditampilkan melalui Gambar 13, sebagai berikut. 


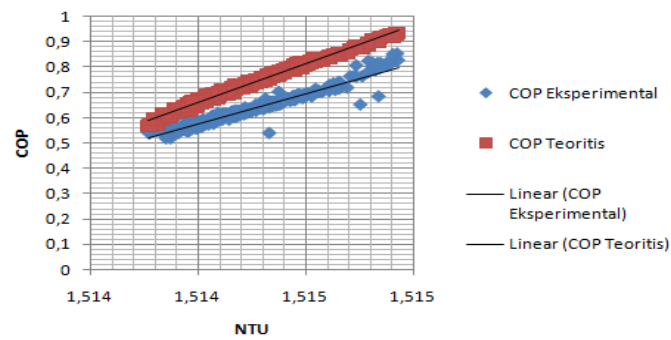

Gambar 11 Grafik NTU dengan COP dengan $V_{\text {udara }}=1 \mathrm{~m} / \mathrm{s}$

Dari grafik pada Gambar 11, dapat dilihat bahwa nilai COP teoritis lebih tinggi dibandingkan nilai COP eksperimental.

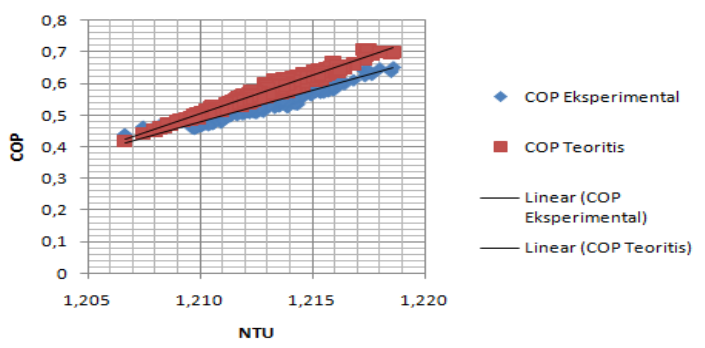

Gambar 12 Grafik NTU dengan COP dengan $V_{\text {udara }}=2 \mathrm{~m} / \mathrm{s}$

Dari grafik pada Gambar 12, dapat dilihat bahwa nilai COP teoritis lebih tinggi dibandingkan nilai COP eksperimental

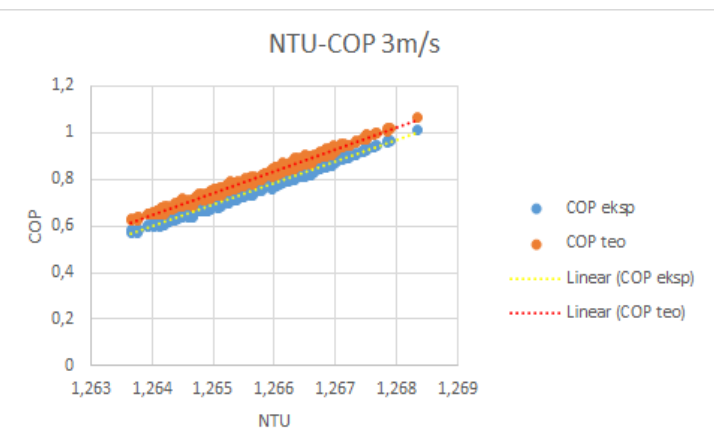

Gambar 13 Grafik NTU dengan COP dengan $V_{\text {udara }}=3 \mathrm{~m} / \mathrm{s}$

Dari grafik pada Gambar 13 diatas, dapat dilihat bahwa nilai COP teoritis lebih tinggi dibandingkan nilai COP eksperimental. Ketiga grafik menunjukkan gejala yang sama yaitu COP dari sebuah perangkat pengganti panas-udara tanah semakin meningkat bila angka NTU aliran udara dalam pipa mengalami peningkatan. Semakin meningkatnya nilai COP dikarenakan suhu udara yang tinggi masuk kedalam perangkat pengganti panas. Dimana suhu yang semakin tinggi, kapasitas panas spesifik akan meningkat juga. Hal ini akan mempengaruhi meningkatnya nilai cooling capacity dari alat Earth Air Heat Exchanger (EAHE). 


\section{Kesimpulan}

Pendinginan ruangan dengan mempergunakan metode sistem transfer kalor dalam lapisan tanah. Dalam analisis perangkat pengganti panas, diketahui koefisien transfer kalor keseluruhan (Overall Heat Transfer Coefficient).

Heat exchanger tipe ini menggunakan tube pada desainnya. Kekurangan dari tubular dan plate heat exchanger adalah koefisien perpindahan panasnya relatif rendah, hingga $60 \%$. Oleh karena itu, Salah satu metode untuk meningkatkan tingkat efisiensi transfer kalor yaitu dengan memperluas permukaan dengan memperggunakan heat sink.. Tujuan penelitian ini adalah untuk menghitung dan membandingkan nilai efektivitas $(\varepsilon)$ dari alat penukar kalor udara tanah hasil eksperimen dan teoritis, dan juga mengetahui nilai Coeficient of Performance secara teoritis dan eksperimen. Hasil yang didapatkan yaitu Average COP Value resultan dari percobaan merupakan 0,63 dalam kelajuan $1 \mathrm{~m} / \mathrm{s}, 0,54$ dalam kelajuan $2 \mathrm{~m} \mathrm{~s}, 0,75$ dalam kelajuan $3 \mathrm{~m} / \mathrm{s}$, dan secara teoritis 0,73 di kelajuan $1 \mathrm{~m} / \mathrm{s}, 0,57$ dalam kelajuan $2 \mathrm{~m} / \mathrm{s}, 0,80$ dalam kelajuan $3 \mathrm{~m} / \mathrm{s}$. Untuk tingkat validitas rata-rata resultan percobaan diperoleh 0,85 dalam kelajuan $1 \mathrm{~m} / \mathrm{s}, 0,93$ diperoleh dalam kelajuan $2 \mathrm{~m} / \mathrm{s}, 0,89$ diperoleh pada kelajuan $3 \mathrm{~m} / \mathrm{s}$, dan hasil teoritis diperoleh pada kelajuan $1 \mathrm{~m} / \mathrm{s}$ adalah $0,995.0,997$ pada $2 \mathrm{~m} / \mathrm{s}, 0,998$ pada $3 \mathrm{~m} / \mathrm{s}$.

\section{Ucapan Terima Kasih}

Penulis menyampaikan rasa terimakasih kepada DRPM DIKTI atas bantuan dana yang diberikan melalui proyek penelitian terapan unggulan perguruan tinggi (PTUPT) tahun 2020.

\section{DAFTAR PUSTAKA}

[1] Y. Cengel, Heat Transfer: A Practical Approach, 2nd ed. New York: Mc Graw-Hill, 2003.

[2] F. P. Incropera and D. P. Dewitt, Introduction to Heat Transfer, 7th ed. New York: John Wiley \& Sons, 2011.

[3] D. Belatrache, S. Bentouba, and M. Bourouis, "Numerical analysis of earth air heat exchangers at operating conditions in arid climates," Int. J. Hydrogen Energy, vol. 42, no. 13, pp. 8898-8904, 2017, doi: 10.1016/j.ijhydene.2016.08.221.

[4] H. Ben Jmaa Derbel and O. Kanoun, "Investigation of the ground thermal potential in tunisia focused towards heating and cooling applications," Appl. Therm. Eng., vol. 30, no. 10, pp. 1091-1100, 2010, doi: 10.1016/j.applthermaleng.2010.01.022.

[5] T. S. Bisoniya, "Design of earth-air heat exchanger system," Geotherm. Energy, vol. 3, no. 1, 2015, doi: 10.1186/s40517-015-0036-2.

[6] H. BULUT, Y. DEMIRTAŞ, R. KARADAĞ, and İ. HİLALİ, "ID 57 Presentation Experimental analysis of an Earth Tube Ventilation system under Hot and Dry Conditions H . BULUT ID 57 - Experimental Analysis of an Earth Tube Ventilation System under Hot and Dry Climatic Conditions," 2015.

[7] J. Pfafferott, "Evaluation of earth-to-air heat exchangers with a standardised method to calculate energy efficiency," Energy Build., vol. 35, no. 10, pp. 971-983, 2003, doi: 10.1016/S0378-7788(03)00055-0.

[8] J. Vaz, M. A. Sattler, R. da S. Brum, E. D. dos Santos, and L. A. Isoldi, "An Experimental Study On The Use of Earth-Air Heat Exchanger (EAHE)," Energy and Buildings., vol. 72, pp. 122-131, 2014.

[9] H. Wu, S. Wang, and D. Zhu, "Modelling and evaluation of cooling capacity of earth-airpipe systems," Energy Convers. Manag., vol. 48, no. 5, pp. 1462-1471, 2007. 
[10] D. Yang, Y. Guo, and J. Zhang, "Evaluation of the thermal performance of an earth-to-air heat exchanger (EAHE) in a harmonic thermal environment," Energy Convers. Manag., vol. 109, pp. 184-194, 2016, doi: 10.1016/j.enconman.2015.11.050.

[11] P. Hollmuller and B. Lachal, "Air-soil heat exchangers for heating and cooling of buildings: Design guidelines, potentials and constraints, system integration and global energy balance," Appl. Energy, vol. 119, pp. 476-487, 2014, doi: 10.1016/j.apenergy.2014.01.042.

[12] J. P. Holman, Perpindahan Kalor, 2nd ed. Jakarta: Erlangga.

[13] F. Kreith and M. S. Bohn, Principles Of Heat Transfer, 4th ed. New York: Harper and Row, 1986.

[14] R. Kumar, A. R. Sinha, B. K. Singh, and U. Modhukalya, "A design optimization tool of earth-to-air heat exchanger using a genetic algorithm," Renew. Energy, vol. 33, no. 10, pp. 2282-2288, 2008. 